\title{
КОНСТРУИРОВАНИЕ КОНДЕНСИРОВАННЫХ ГЕТЕРОЦИКЛИЧЕСКИХ СИСТЕМ НА ОСНОВЕ РЕАКЦИИ ЭЛЕКТРОНОДЕФИЦИТНЫХ 3-ВИНИЛХРОМОНОВ С ЦИАНАЦЕТАМИДОМ
}

\author{
Н.М. Чернов', Р.В. Шутов', Н.Ю. Сипкина², И.П. Яковлев' \\ ${ }^{1}$ Кафедра органической химии, Санкт-Петербургский государственный \\ химико-фармацевтический университет, \\ 197022, Россия, Санкт-Петербург, ул. проф. Попова, 14.
}

${ }^{2}$ Испытательная лаборатория (ЦККЛС), Санкт-Петербургский государственный химикофармацевтический университет,

197022, Россия, Санкт-Петербург, ул. проф. Попова, 14.

DOI:10.19163/MedChemRussia2021-2021-46Ｅ-mail: nikita.chernov@pharminnotech.com

3-Винилхромоны 1, содержащие в винильном фрагменте электроноакцепторную группу (EWG), зарекомендовали себя как многоцелевые структурные блоки для построения на их основе конденсированных гетероциклических систем [1, 2]. В частности, наличие в их структуре нескольких электрофильных центров с резко отличающейся реакционной способностью позволило создать эффективный метод синтеза хромено[4,3-d]пиримидинов [2]. При этом известно, что данные фенантреноподобные соединения часто проявляют анальгезирующую и антиагрегантную активность [3]. Продолжая данные исследования, мы изучили взаимодействие электродефицитных 3-винилхромонов 1 с представителем 1,3-C,Nбинуклеофилов - цианацетамидом (ЦАА).<smiles>Cc1ccc2c(c1)-c1[nH]c(=O)c(C)cc1C(CC(C)(C)C)O2</smiles>

Протекающая при этом реакция ANRORC привела к двух рядам продуктов: хромено[4,3-b]пиридонам 2 и иминопроизводным 3, которые затем гидролизовались до пирано[3,2-с]хроменов 4. Реакцию вели в этаноле в основной среде. Направление реакции сильно зависит от выбора катализатора, при этом использование ненуклеофильных сильных органических оснований (ДБУ, тетраметилгуанидин) способствует образованию продуктов 3 с выходами вплоть до 96\% (по данным ВЭЖХ, препаративные - до 88\%). Напротив, применение триэтиламина при $20^{\circ} \mathrm{C}$ позволило в качестве основных продуктов выделять пираны 3 (выходы по ВЭЖХ до 78\%).

\section{Литература}

[1] N. Chernov, R. Shutov, V. Sharoyko, N. Kuz'mich, A. Belyakov, and I. Yakovlev, Eur. J. Org. Chem. 2017, 2836-2841

[2] N. Chernov, R. Shutov, A. Potapova, and I. Yakovlev, Synthesis. 2020, 51, 1-10

[4] O. Bruno, C. Brullo, S. Schenone, F. Bondavalli, A. Ranise, M. Tognolini, V. Ballabeni, and E. Barocelli, Bioorg. Med. Chem. 2004, 12, 553-561 